\title{
Effect Of Services, Products And Prices On Purchase Decisions At PT. Surya Medika Utama Surabaya
}

\author{
Aliyu Rofika Romadhona dan I Gede Arimbawa \\ Program Studi Manajemen, Fakultas Ekonomi Dan Bisnis \\ Universitas Narotama Surabaya \\ Email author: gede.arimbawa@narotama.ac.id
}

\begin{abstract}
The problems discussed in this study are: whether services, products, and prices have a significant effect on purchasing decisions simultaneously and whether services, products, and prices have a significant effect on purchasing decisions partially. The purpose of this study is to analyze and analyze whether services, products, and prices simultaneous influence on purchasing decisions and to analyze tests and analyze whether services, products, and prices partially influence purchasing decisions. The object of this research was carried out on customers from PT. Surya Medika Utama Surabaya.
\end{abstract}

\section{Keyword:}

Services, products, prices and purchase decisions

\section{Pendahuluan}

\subsection{Latar Belakang}

Di era globalisasi saat ini persaingan di bidang perdagangan sangatlah ketat, baik itu produk maupun jasa. Dan sekarang ini banyak bermunculan belanja secara online melalui internet. Sehingga banyak sekali para pengusaha yang berlomba-lomba membuat website sehingga dapat menjangkau para pengguna internet dan lebih mendekatkan diri dengan para pelanggannya.

Distributor alat kesehatan merupakan perusahaan yang bergerak di bidang jasa, karena pada perusahaan ini mereka tidak membuat produk tetapi hanya menyalurkan produk ke end user atau pelanggan terakhir. Alat kesehatan disini bukanlah alat kesehatan yang dapat langsung dikonsumsi atau dipakai langsung oleh pasien melainkan perlu adanya keterlibatan dokter spesialis dan rumah sakit. Adalah implant yang merupakan produk yang diperuntukkan untuk pasien-pasien yang mengalami kecelakaan atau para manula yang mana sendinya sudah mulai tidak bisa di gerakkan atau bisa disebut traumatologi.

PT. Surya Medika Utama adalah salah satu distributor yang ada di Surabaya. Perusahaan ini merupakan distributor alat kesehatan yang berupa implant orthopaedi. Dan setiap pasar pasti memiliki kompetitor yang tidak terkecuali distributor alat kesehatan di bidang implant orthopaedi.

Dari uraian latar belakang diatas, maka penulis tertarik untuk mengangkat penelitian dengan judul : Pengaruh Pelayanan, Produk Dan Harga Terhadap Keputusan Pembelian di PT. Surya Medika Utama Surabaya.

\subsection{Perumusan Masalah}

Berdasarkan uraian latar belakang diatas, terdapat beberapa rumusan masalah yang terkait dengan bahasan penelitian ini. Rumusan tersebut adalah :

1. Apakah pelayanan, produk dan harga berpengaruh signifikan terhadap keputusan pembelian secara simultan?

2. Apakah pelayanan, produk dan harga berpengaruh signifikan terhadap keputusan pembelian secara parsial?

\subsection{Tujuan Penelitian}

Tujuan dari penelitian yang telah disesuaikan dengan rumusan masalah di atas, yaitu :

1. Untuk menganalisis dan menganalisa apakah pelayanan, produk dan harga berpengaruh secara simultan terhadap keputusan pembelian.

2. Untuk menganalisis menguji dan menganalisa apakah pelayanan, produk dan harga berpengaruh secara parsial terhadap keputusan pembelian.

\subsection{Manfaat Penelitian}

Manfaat dari penelitian ini diharapkan dapat membantu baik secara praktis maupun secara teoritis. Manfaat tersebut ialah :

1. Manfaat Praktis 
Hasil penelitian ini diharapkan dapat menjadi tambahan pengetahuan bagi PT. Surya Medika Utama bahwa terdapat beberapa faktor yang mempengaruhi keputusan pembelian yakni layanan, produk dan harga.

2. Manfaat Teoritis

Penelitian ini diharapkan dapat menambah pengetahuan dan informasi tambahan untuk pembaca dan kalangan akademis. Di lain sisi penelitian ini juga akan menjadi wadah dimana penulis bisa mengaplikasikan ilmu yang di dapat dari perkuliahan terutama ilmu manajemen pemasaran terutama yang berkaitan dengan keputusan pembelian.

\subsection{Batasan Penelitian}

Supaya masalah ini lebih terarah dan fokus, maka batasan penelitian yang dilakukan oleh penulis hanya membahas pengaruh pelayanan, produk dan harga terhadap keputusan pembelian. Apabila terdapat variabel lain yang digunakan maka variabel tersebut tidak dibahas dalam penelitian ini.

\section{Tinjauan Pustaka}

\subsection{Pengertian Pemasaran}

Pemasaran merupakan sebuah kegiatan dimana kegiatan ini wajib hukumnya bagi sebuah perusahaan. Tanpa adanya kegiatan pemasaran maka perusahaan tidak akan bisa menjual produk atau jasanya. Dengan tidak bisa menjual barang atau produknya maka perusahaan tidak akan memperoleh omzet atau penjualan sehingga dapat dipastikan perusahaan tersebut akan mengalami kerugian yang lambat laun akan mengakibatkan perusahan gulung tikar atau bangkrut. Terdapat beberapa pendapat tentang pemasaran yang dikemukakan oleh para ahli.

\subsection{Bauran Pemasaran}

Bauran pemasaran atau yang lebih dikenal dengan istilah marketing mix merupakan hal penting yang harus diperhatikan dalam pemasaran. Dalam bauran pemasaran terdiri dari 4P yakni product, price, place dan promotion.

Menurut Philip Kotler dan Gary Armstrong (2008: 48), marketing mix adalah perangkat taktis yang dapat dikendalikan, melalui product, price, place dan promotion yang dipadukan oleh perusahaan untuk menghasilkan respon yang diinginkan.

\subsection{Pelayanan}

Menurut Antonius Atoshoki Gea Antonina Panca Yuni Wulandari (2008: 345) pelayanan lebih bersifat intangibles, tidak dapat dilihat dan diraba, sehingga penggunaannya hanya bisa merasakan melalui pengalaman langsung.

Pelayanan adalah suatu hal yang bersifat intangibles yang hanya bisa dirasakan dan diketahui melalui pengalaman saja. Karena sifatnya yang intangibles sangatlah sulit untuk menilainya dibutuhkan alat yang khusus untuk menilainya seperti menyebarkan kuesioner untuk mengetahui apakah pelayanan yang telah diberikan sudah sesuai dengan yang diharapkan oleh konsumen.

\subsection{Keputusan Pembelian} berikut:

Kotler (2002: 183) menyimpulkan indikator keputusan pembelian berdasarkan black box kotler sebagai

1. Pemilihan produk

Pemilihan produk berdasarkan kemantapan pada sebuah produk, kebiasaan dalam membeli serta memberikan rekomendasi kepada orang lain dan melakukan pembelian ulang (Kotler, 1995).

2. Pemilihan merek

Pemilihan merek dilihat dari identitas atau elemen-elemen merek terdiri atas nama merek (brand names), juru bicara (spokespeople), slogan, jingles, kemasan, signage (Keller, 2003).

3. Pemilihan saluran pembelian

Pemilihan saluran pembelian dimana saluran pembelian merupakan saluran distribusi yang terdiri dari sekelompok pedagang dan agen perusahaan yang mengkombinasikan anatara pemindahan fisik dan nama dari suatu produk untuk menciptakan kegunaan bagi pasar tertentu (Kotler dan Amstrong, 2008).

4. Penentuan waktu pembelian

Konsumen tahu waktu yang tepat untuk mengambil keputusan pembelian dimana ini menyangkut tersedianya uang untuk membeli suatu produk (Swastha Basu, 2005).

5. Jumlah pembelian

Konsumen mengambil keputusan berapa unit produk yang akan dibeli di suatu saat yang mungkin pembelian lebih dari satu unit (Swastha Basu, 2005). 


\subsection{Kerangka Konsep Penelitian}

Penelitian ini memiliki tiga variabel bebas (variabel X) yaitu pelayanan, produk, dan harga. Ketiga variabel bebas tersebut berkaitan dengan keputusan pembelian (variabel Y) pada perusahaan yang akan diteliti oleh peneliti. Sehingga, dalam penelitian ini akan dibahas bagaimana pengaruh ketiga variabel bebas tersebut mempengaruhi variabel terikat. Dalam penelitian ini peneliti menggunakan bantuan program SPSS untuk menghitung hasil analisisnya.

\subsection{Hipotesis}

Dari rumusan masalah yang terdapat di Bab 1 peneliti mengambil beberap hipotesis yaitu:

1. Terdapat pengaruh signifikan secara simultan dari variabel pelayanan, produk dan harga terhadap keputusan pembelian di PT. Surya Medika Utama Surabaya.

2. Terdapat pengaruh signifikan secara parsial dari variabel pelayanan, produk dan harga terhadap keputusan pembelian di PT. Surya Medika Utama Surabaya.

\section{Metode Penelitian}

\subsection{Pendekatan Penelitian}

Pada penelitian kali ini peneliti menggunakan pendekatan penelitian yang digunakan adalah kuantitatif. Metode ini menggunakan cara pengumpulan data menggunakan kuesioner dimana analisis datanya dalam bentuk numerik dengan bantuan program SPSS untuk pengolahan datanya.

\subsection{Populasi dan Sampel}

\subsubsection{Populasi}

Menurut Sugiyono (2004: 57) Populasi adalah wilayah generalisasi yang terdiri dari atas obyek atau subyek yang mempunyai kuantitas dan karakteristik tertentu yang ditetapkan oleh peneliti untuk dipelajari dan kemudian ditarik kesimpulannya. Dalam penelitian ini populasi yang dipakai oleh peneliti ialah konsumen potensial dan konsumen yang telah menjadi pelanggan dari PT. Surya Medika Utama Surabaya.

\subsubsection{Sampel}

Dalam penelitian ini untuk menentukan jumlah sampel digunakan Rumus Slovin sebagai berikut :

Dimana :

$$
n=\frac{N}{1+N e^{2}}
$$

$\mathrm{N} \quad=$ Jumlah populasi

$\mathrm{n} \quad=$ Jumlah sampel

ditolerir (10\%)

$=$ Persen kelonggaran ketidaktelitian karena kesalahan pengambilan sampel yang masih dapat

Berdasarkan rumus Slovin diatas, maka perhitungan jumlah sampelnya adalah

$$
n=\frac{50}{1+50(0,05)^{2}}=44
$$

Dengan demikian jumlah responden dalam penelitian ini sebanyak 44 orang.

\subsection{Jenis, Sumber dan Teknik Pengambilan Data}

Dalam penelitian ini jenis data yang digunakan adalah data kuantitatif. Dimana data yang diperoleh dalam bentuk numerik. Sedangkan untuk sumber datanya adalah data primer yang mana data tersebut diperoleh langsung dari obyek yang sedang diteliti. Sedangkan untuk teknik pengambilan data diperoleh dari data internal perusahaan, penyebaran kuesioner dan wawancara.

\subsection{Teknik Analisis Data}

\subsubsection{Uji Validitas}

Sugiyono (2004) memberikan kesimpulannya tentang cara yang digunakan untuk menguji validitas yakni cara yang digunakan adalah dengan analisa item, dimana setiap nilai yang ada pada setiap butir pertanyaan dikorelasikan dengan total nilai seluruh butir pertanyaan untuk suatu variabel dengan menggunakan rumus korelasi product moment. Syarat minimum untuk dianggap valid adalah nilai $r$ hitung $>$ dari nilai $r$ tabel. 


\subsection{Uji Reliabilitas}

Indikator pengukuran reliabilitas menurut Sekaran (2000: 312) yang membagi tingkatan reliabilitas dengan kriteria sebagai berikut :

Jika alpha atau $r$ hitung:
1. $0,8-1,0$
$=$ Reliabilitas baik
2. $0,6-0,799$
$=$ Reliabilitas diterima
3. kurang dari 0,6
$=$ Reliabilitas kurang baik

\subsection{Transformasi Data Ordinal ke Interval}

Dikarenakan data yang telah dikumpulkan berbentuk data ordinal, sedangkan syarat dari uji regresi ialah data minimal berbentuk interval, maka untuk menganalisa regresi data harus dinaikkan skala pengukurannya sehingga dari skala ordinal berubah menjadi skala interval. Cara menaikkan skala pengukuran data dapat menggunakan metode interval berurutan (Method of Successive Interval), yang dilkukan dengan bantuan program komputer.

\subsection{Analisa Regresi Linier Berganda}

Dalam penelitian ini memakai model dan teknik analisa data yang menggunakan pendekatan regresi linear berganda. Peneliti menggunakan software pengolah data yakni SPSS dan Microsoft Excel 2007. Tetapi sebelum menganalisis regresi berganda akan dilakukan uji kualitas instrumen penelitian, uji normalitas data dan uji asumsi klasik. Model analisa regresi linear berganda pada penelitian ini adalah sebagai berikut :



Arti koefisien $\beta$ ialah apabila nilainya positif (+) hal itu berarti bahwa hubungan yang searah baik itu antara variabel bebas maupun yang terikat. Sehingga jika terjadi peningkatan atau penurunan pada variabel bebas akan diikuti pula oleh variabel terikat. Begitupun dengan sebaliknya apabila koefisien $\beta$ bernilai negatif (-) itu berarti hubungan antara variabel bebas dan terikat saling berlawanan. Sehingga apabila terjadi peningkatan nilai pada variabel bebas maka variabel terikat terjadi penurunan dan sebaliknya.

\section{Hasil Penelitian Dan Pembahasan}

\subsection{Pengaruh Pelayanan terhadap Keputusan Pembelian}

Hasil pengujian hipotesis telah membuktikan tidak terdapat pengaruh antara pelayanan terhadap keputusan pembelian produk PT. Surya Medika Utama, melalui hasil perhitungan yang telah dilakukan diperoleh t.hitung $=1,758>$ t.tabel $=1,684$.

Dengan taraf signifikansi hasil sebesar 0,086 tersebut lebih besar dari 0,05 pengujian ini secara statistik membuktikan bahwa pelayanan berpengaruh positif terhadap keputusan pembelian. Sehingga dapat disimpulkan bahwa tidak ada pengaruh antara variabel pelayanan terhadap keputusan pembelian produk PT.Surya Medika Utama.

\subsection{Pengaruh Produk terhadap Keputusan Pembelian}

Hasil pengujian hipotesis telah membuktikan terdapat pengaruh antara produk terhadap keputusan pembelian produk PT. Surya Medika Utama, melalui hasil perhitungan yang telah dilakukan diperoleh t.hitung $=2,883>$ t.tabel $=1,684$.

Dengan taraf signifikansi hasil sebesar 0,006 tersebut lebih kecil dari 0,05 pengujian ini secara statistik membuktikan bahwa produk berpengaruh negatif terhadap keputusan pembelian. Sehingga dapat disimpulkan bahwa terdapat pengaruh antara variabel produk terhadap keputusan pembelian produk PT.Surya Medika Utama, salah satunya dengan memberikan kualitas produk dengan standar internasional.

\subsection{Pengaruh Harga terhadap Keputusan Pembelian}

Hasil pengujian hipotesis telah membuktikan tidak terdapat pengaruh antara harga terhadap keputusan pembelian produk PT. Surya Medika Utama, melalui hasil perhitungan yang telah dilakukan diperoleh t.hitung $=-0,883<$ t.tabel $=1,684$. 
Dengan taraf signifikansi hasil sebesar 0,382 tersebut lebih besar dari 0,05 pengujian ini secara statistik membuktikan bahwa harga berpengaruh positif terhadap keputusan pembelian. Sehingga dapat disimpulkan bahwa tidak ada pengaruh antara variabel harga terhadap keputusan pembelian produk PT.Surya Medika Utama.

\subsection{Pengaruh Pelayanan, Produk dan Harga terhadap Keputusan Pembelian}

Berdasarkan hasil pengujian hipotesis secara simultan (Uji F) dari variabel independen (bebas) yaitu pelayanan, produk dan harga secara simultan berpengaruh terhadap variabel dependen (terikat) yaitu keputusan pembelian. Hal ini dibuktikan dari nilai signifikansi 0,044 atau kurang dari 0,05 dan Fhitung adalah 2,954 > Ftabel 2,84.

Sedangkan untuk hasil pengujian hipotesis secara parsial (Uji t) dari ketiga variabel independen (bebas) yakni pelayanan, produk dan harga, hanya variabel produk saja yang mempunyai pengaruh secara parsial terhadap variabel terikat (keputusan pembelian). Untuk variabel pelayanan dan harga tidak memiliki pengaruh secara parsial terhadap keputusan pembelian dari PT. Surya Medika Utama.

\section{Kesimpulan Dan Saran}

\subsection{Kesimpulan}

1. Dari uji $\mathrm{F}$ atau ANOVA didapat jika Fhitung dari penelitian ini yang menyatakan bahwa variabel independen (pelayanan, produk, harga) secara simultan berpengaruh signifikan terhadap variabel dependen (keputusan pembelian) produk dari PT. Surya Medika Utama Surabaya.

2. Dari hasil uji t :

1) Pelayanan (X1) tidak berpengaruh secara parsial terhadap keputusan pembelian.

2) Produk (X2) berpengaruh secara parsial terhadap keputusan pembelian.

3) Harga (X3) tidak berpengaruh secara parsial terhadap keputusan pembelian.

\subsection{Saran}

Dari hasil simpulan yang telah peneliti sampaikan di atas, berikut ini penulis memberikan rekomendasi berupa bebarapa saran yang bisa digunakan oleh PT. Surya Medika Utama Surabaya dalam memasarkan produknya ke customer, sebagai berikut ini :

1. Memberikan pelayanan yang prima terhadap semua customer dengan tidak membanding-bandingkan perlakuan khusus antara satu customer dengan customer lainnya. Sehingga setiap customer memperoleh pelayanan yang sama.

2. Selalu memberikan kualitas produk yang baik dan menjaga kualitas produk tersebut. Dengan harapan kedepannya dapat membuat produk yang berstandar Internasional, sehingga kualitas produk diterima oleh masyarakat Internasional dan pangsa pasar pun juga dapat meluas hingga Internasional.

3. Memberikan harga yang mampu bersaing dengan para kompetitor, agar mudah diterima oleh para customer tetap maupun customer potensial yang harapannya dapat menjadi customer tetap dari PT. Surya Medika Utama Surabaya.

Untuk penelitian selanjutnya diharapkan dapat meneliti variabel lain yang dapat mempengaruhi keputusan pembelian customer di PT. Surya Medika Utama Surabaya selain pelayanan, produk dan harga sehingga dapat membantu dalam hal meningkatkan penjelasan tentang keputusan pembelian customer di PT. Surya Medika Utama Surabaya.

\section{DAFTAR PUSTAKA}

Gea, A. A., P. Y. W. 2008. Relasi dengan Dunia (Alam, Iptek dan Kerja). Jakarta: Elex Media Komputindo.

Kotler, P. 2002, Manajemen Pemasaran, Edisi Millenium, Jilid 2, PT Prenhallindo, Jakarta.

Kotler, P., G. Armstrong. 2008. Prinsip-prinsip Pemasaran,Jilid 1, Erlangga, Jakarta.

Sugiyono. 2004. Metode Penelitian. Bandung: Alfabeta

Swastha, B., Irawan, 2005, Asas-asas Marketing, Liberty, Yogyakarta 